\title{
Ethnomathematics in Kafa, Ethiopia: Number Sense and its Level of Inclusion in School Curriculum
}

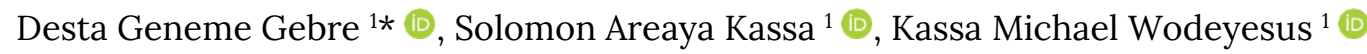

${ }^{1}$ Addis Ababa University, ETHIOPIA

*Corresponding Author: destagenemegebre@gmail.com

Citation: Gebre, D. G., Kassa, S. A., \& Wodeyesus, K. M. (2021). Ethnomathematics in Kafa, Ethiopia: Number Sense and its Level of Inclusion in School Curriculum. Mediterranean Journal of Social \& Behavioral Research, 5(3), 41-50. https://doi.org/10.30935/mjosbr/11291

\begin{abstract}
The purpose of this study was to find out the indigenous number and number sense of people in Kafa and to explore its level of integration to school curriculum. To this end, the study followed a qualitative research method which utilized ethnographic case study (embedded) design. Data were collected from 22 key participants through interview, observation, and focus group discussion. In addition, content analysis was used to investigate the level of integration of number and number sense to school curriculum. Accordingly, the study found that base six (maqoo) and base sixty (uddoo) counting systems, fractions and measurement related mathematical systems are found embedded in Kafa agricultural setting. The study further found that indigenous number and number sense of Kafa people were partially integrated in school curriculum. The implication of the finding is that there is a need to improve the existing school curriculum in a way it covers indigenous number and number sense of the people in Kafa.
\end{abstract}

Keywords: indigenous counting, indigenous number, people of Kafa, ethnomathematics, integration Received: 30 Jun. $2021 \bullet$ Accepted: 7 Sep. 2021

\section{INTRODUCTION}

School mathematics that students are learning today in Africa is the mathematics of mathematicians (Ayalew \& Areaya, 2021; Bishop, 1988; Mosimege, 2017). According to Shizha (2014), the African education system today has been built on the view that mathematics is objective and culture free. As a result, students have very low interest to learn mathematics (Kaino, 2013) which in turn resulted low achievement of mathematics at school (Orey \& Rosa, 2011; Shizha, 2014; Webb, 2013). Nowadays, there is worldwide initiative to re-construct indigenous knowledge and to integrate into school curriculum.

Currently, the Ethiopian education system has recognized the significance of integrating contextual knowledge of people into school curriculum. It was indicated in mathematics education guideline documents in that mathematics is a product of modelling real situations (Ayalew \& Areaya, 2021; MoE, 2002).

According to socio-cultural perspective of education, the inclusion of human language, rules and agreement in school mathematics curriculum is one of the strategies to make mathematics meaningful to learners (Ernest, 1991). Furthermore, researchers in Ethiopia agree that mathematics is interconnected with people's practice and it is cultural (Ayallew \& Areaya, 2021; Hilluf, 2015; Faris, 2012; Tesfamichael et al., 2021).
Different empirical evidences conducted on mathematics education also indicate that social life related mathematics education helps children's mathematics learning to be meaningful (Bishop, 1988; Kaino, 2013; Orey \& Rosa, 2006, 2014). For example, a study conducted in Africa by Kaino (2013) in Tchkwe tribe cultural setting in Angola showed that Ethnomathematical curriculum was found to promote mathematizing by students which lead students to determine mathematical rules and laws.

According to Kaino the curriculum design process in Africa should include indigenous knowledge of a society for clear understanding of concepts and for long term retention of mathematical knowledge on the side of learners.

Mathematics used outside of school is a type of modelling; it is a way of representing reality so that further knowledge about reality can be obtained. In this regard, integration of Ethnomathematics to school curriculum creates an opportunity for learners to mathematize the cultural practices (Kaino, 2013, Menon, 2013; Nunes, 1992; Tesfamichael et al., 2021). Thus, in connection to this, Nunes (1992) argues that brining out-of - school indigenous mathematics into the school is important and this is possible when it is integrated into school curriculum. Therefore, identifying indigenous knowledge in general, indigenous number and number sense in particular is important in this regard. Furthermore, exploring the level of inclusion is among important issues of investigation, in the current study. 


\section{Ethnomathematics}

There are two fundamental conceptions on Ethnomathematics: general and specific. In general view, Ethnomathematics has been conceived as program of study consisting of history, pedagogy, philosophy and research activities in mathematics education (D’Ambrosio, 1990; Orey \& Rosa, 2011). By extension, Ethnomathematics has been defined as a program of study that explores varying forms of mathematics that emanates from different group of people with different modes of thought. Similarly, Orey and Rosa (2011) defined Ethnomathematics as a program of study that deals with what and how we teach mathematics in the context of the school culture and society. In this regard, the conception of Ethnomathematics has been connected with research program, subject of study, philosophy of mathematics and social theory of mathematics that deal with interconnection between culture, language, epistemology and mathematics. On the other hand, Ethnomathematics has been conceptualized as mathematical idea, concept of a certain society or group of people at a specific cultural setting (D’Ambrosio, 1985; Frankenstein, 2014). However, there exists a debate on the boundary of cultural group used in the definition of Ethnomathematics. While some associated the cultural group with "illiterate, colonized and irrelevant" (Asher \& Asher, 1997), some others associated the cultural groups with "people that have similar context, language and socio-cultural background" (D’Ambrosio, 1985; Frankenstein, 2014; Orey \& Rosa, 2011). The center of this disagreement fundamentally depends on the individuals' attempt to extend or stop the former colonization agenda in the developing countries like Africa (Faris, 2012; Nsamenang \& Tchombe, 2011; Shizha, 2014). In this regard, those who conceptualize Ethnomathematics, as mathematics of illiterate perceive mathematics as objective and universal, and, thus, they attempt to transmit their culture and their knowledge to the society of developing countries (Orey \& Rosa, 2011; Shizha, 2014). To the contrary, those scholars who are attempting to actualize real development in the developing countries struggle to integrate Ethnomathematical knowledge to mathematics education. Pertaining to this; researchers of this article believe that integrating Ethnomathematics to school curriculum is providing complete view on mathematics and bridging the gap between mathematics and cultural practices

\section{School Curriculum}

The conception of curriculum is many things to many people. As Ornstein and Hunkins (2018) point out, the definition of curriculum perpetuates some assumptions and beliefs. The purpose of school, how students should learn, who should learn what and how school learning should be organized are among the issues of concern when scholars define the term curriculum (Pinar, 2004). According to Pinar (2004, p. 186), the conception of curriculum is highly symbolic. It contains issues of history, race, gender, phenomenology, autobiography, aesthetic, theology and international issues. Due to these multifaceted issues implicitly attached to it, it has complicated conversation. These dialogues and conversations create multiplicity with respect to its conceptions and definitions. According to Oliva (2005), the definition of curriculum in schools differs due to the purpose, context and strategies that schools adopt to follow. In this regard, Oliva (2005) described curriculum as an elusive, almost esoteric term that always need operational definition guided by the basic assumptions of schools. Oliva further indicated that the amorphous nature of curriculum that ranges from simple to broad has resulted in multiple interpretations and conceptions(Oliva,
2005, p. 3). Ornestein and Hunkeins (2018, p. 19) also described that the definition of curriculum is influenced by multiple factors as educational philosophy, politics and culture of society. Based on the fundamental issues of education, its definition contains multiple variable components. Pertaining to this, they described the curriculum as a field of study that has been characterized by elusive, fragmentary, and confusing which stretches from very narrow as subject thought at school to broad as the experience of students (Ornestein \& Hunkeins, 2018, p. 19).

As Kelly (2004) described curriculum is equated with syllabus which is limited to contents and body of knowledge that schools intend to transmit (p. 4). Further review on the detail of curriculum shows that curriculum definition encompasses very simplistic ideas as contents in the textbook and training manuals (Faris, 2012). According to Areaya (2008), major variations on the definitions of curriculum are attributable to variations on the meaning and values of education emphasized in general. Oliva (2005) indicated the multiplicity of definitions on curriculum when the author said the curriculum definition can be conceived as content thought in schools in narrower sense and as both planned and hidden experiences of learners in the school and outside school setting (Oliva, 2005, p. 3). Despite these multiple definitions and conception, in the current study, curriculum refers to the textbooks, teacher's guide and the syllabi of school curriculum. Accordingly, school curriculum in this paper refers to lower primary school mathematics syllabi, textbooks and teachers' guide designed to teach mathematics in primary school in Kafa, Ethiopia.

\section{Integration}

Integration connotes different ideas for different person. It has multiple conceptions and definitions. However, it is conceptualized on the assumption that learning is not an isolated event and that connecting ideas across subjects, concepts and themes is an important component of deep understanding (Munro, 2017). According to Albeta Education (2007), integration in curriculum refers to the approach in which curriculum experts purposively draw together knowledge, skill, attitudes and values from or across subject areas to develop a more powerful understanding of ideas (p. 2). Loepp (2000) further described the importance of setting boundary for the issue of integration when saying integration should be conceived within a particular subject than wider. According to Schumacher (2016), the process of bringing two or more ideas within or among subject/s in order to make learning meaningful and full for understanding is termed integration in curriculum. Despite variations evident in the definitions, it deals with connecting ideas, concepts and themes of subjects together in order to make curriculum more meaningful, complete and valuable. Integration, in this paper, refers to the process of including indigenous mathematics to school curriculum so that students learn mathematics meaningfully.

According to Loepp (2000), integration should be standard based, meaningful and consistent. The approach should have underlining principles in order to make the curriculum relevant and should have a positive add to students' learning. In this regard, Davison, Miller and Methny (1995) pointed out that well planned integration creates opportunity for learners to apply scientific knowledge in real situations, assist students to deal with contexts, contents and problems from variety culture (p. 226). Integration, in this case, is providing complete view, knowledge, skill and attitude from multiple knowledge systems 
so that learners get full package of knowledge from different knowledge systems.

Integration of indigenous mathematical knowledge to school curriculum is about making school mathematics contextual in terms of its contents, methods and processes that predominantly take the owners and users of the education system at the center. According to Ronah (2017), integration of indigenous knowledge to school curriculum provides alternative ways of solving problems, eases understanding and making the learning environment rich and aspiring to learners.

We believe that school curriculum need to be built on the assumption that Indigenous knowledge integration to school curriculum makes students' learning meaningful. According to Adam, Alangui and Barton (2003), school curriculum need to be constructed in consideration with students' experience, knowledge and ways of life. The epistemology, the content, the classroom culture and the approach to learning mathematics should be connected with students' experience and their prior knowledge.

The school curriculum, in the current study refers to primary school mathematics syllabi and students' textbooks. Despite it contains four strands: number, geometry, measurement and statistics $(\mathrm{MoE}$, 2002); this study attempted to explore the incorporation of number and number sense in the curriculum. To this end, contents of primary school curriculum in Kafa were analyzed to explore the level of integration of indigenous number and number sense in school curriculum.

\section{Statement of the Problem}

In Ethiopia, both the former education and training policy (1994) and the current education road map (2018) acknowledge that Ethnomathematical knowledge of people in Ethiopia should be integrated to school curriculum so as to make students' learning meaningful. It is indicated that school curriculum should be organized in a way it contains students' prior mathematical experience and indigenous knowledge of the society (MoE, 2014; MoE, ESC, 2018). However, we argue that integration is beyond recognition. It needs exploring and identifying mathematical knowledge of people within a particular context. In Ethiopia, Indigenous mathematical knowledge of people is not documented in the way it could be integrated in school curriculum (Ayalew \& Areaya, 2021; Hailu, 2016). Our study was planned to fill this gap through exploring and documenting number and number sense of Kafa people in Ethiopia. Furthermore, some general studies conducted in Ethiopia (Nasir \& Tefera, 2017; Solomon, 2012) reported that Ethiopian education system does not contain indigenous knowledge of people in Ethiopia. On the other hand, Hilluf (2015) based on a study conducted in Khmira people's setting reported that Ethnomathematics in the setting is integrated in lower primary school curriculum but it is infrequent in upper primary. Despite Hilluf's study was not related to primary school curriculum, the authors of this paper believe that exploring lower primary school curriculum and identifying the level of integration is paramount in Ethiopia. In addition to this, absence of study conducted in Kafa together with very few study conducted in Ethiopia initiated the authors of this study to undergo this research in Kafa, Ethiopia.

\section{Objectives of the Study}

The objective of this study was to explore indigenous number and number sense in Kafa, Ethiopia and find out how the knowledge is integrated in primary school curriculum of Kafa, Ethiopia.

\section{Research Questions}

By way of addressing the aforementioned objectives, the study answered the following research questions:

1. What number and number sense is available in the agricultural practices of people in Kafa?

2. Which indigenous number and number sense of Kafa people is/are integrated in primary school curriculum?

\section{METHODOLOGY}

This study was qualitative which explored number and number sense of people in Kafa, Ethiopia and described the inclusion of number and number sense of Kafa people in primary school curriculum. As indicated in the intent of the study, data collection was done through qualitative methods followed by directed content analysis run on primary school curriculum in Kafa, Ethiopia. There were two phases of data collection. The first data collection was done through interview, observation and FGD. The second data was collected through content analysis template designed to explore primary school curriculum. For this section data was collected through directed thematic analysis.

\section{Data Collection Instruments}

We used multiple data collection tools such as observation, interview, focus group discussion and document analysis. Accordingly, data was collected from 22 key informants. The second phase of data was collected through content analysis template. This assisted the researchers to explore the inclusion of indigenous number and number sense in primary school curriculum.

\section{Methods of Data Analysis}

Data analysis in qualitative study involves the process of coding, categorizing and building analytic description. There were two portions of data analysis in the current study. The first phase dealt with the analysis that investigated indigenous number and number sense of the people in Kafa, Ethiopia and the second phase dealt with exploring the integration of the knowledge to school curriculum. To analyze the data, we used Yin's (2011) data analysis framework followed by Bishop (1988)'s classification of universal mathematical practices.

\section{Analysis of the Text of School Curriculum}

Content analysis can be done qualitatively. It is the process in which the researcher carefully examines the contents in the data of text (Creswell, 2007). To this end, words and phrases that reflect indigenous number and number sense were counted and percentage was used to determine the level of inclusion of Indigenous number and number sense. Furthermore, qualitative descriptions using words were used to visualize the way how indigenous number and number sense were integrated in the school curriculum.

\section{RESULTS}

Number and Number sense in Agricultural practices of people in Kafa

\section{Counting in Maqqoo and Uddoo}

People of Kafa use counting in maqqoo and uddoo as part of day-today practice. There is strong societal need to use this mathematical knowledge. In this regard, they use number words from one to five as 
Table 1. Maqqoo and base six numerations

\begin{tabular}{ccccccccc}
\hline Number & Name in Kafinoono & In base six & Number & Name in Kafinoono & In base six & Number & Name in Kafinoono & In base six \\
\hline 1 & Ikkoo & 1 & 7 & Ikkee Maqqaa ikkoo & 11 & 13 & Guttee maqqaa ikkoo & 21 \\
\hline 2 & Guttoo & 2 & 8 & Ikkee Maqqaa guttoo & 12 & 14 & Guttee maqqaa guuttoo & 22 \\
\hline 3 & Keemo & 3 & 9 & Ikkee Maqqaa keemo & 13 & 15 & Guttee maqqaa keemo & 23 \\
\hline 4 & Awuddoo & 4 & 10 & Ikkee Maqqaa awuddoo & 14 & 16 & Guttee maqqaa awuddoo & 24 \\
\hline 5 & Uuchoo & 5 & 11 & Ikkee Maqqaa uuchoo & 15 & 17 & Guttee maqqaa uuchoo & 25 \\
\hline 6 & Ikkee Maqqoo & 10 & 12 & Guttee maqqoo & 20 & 18 & Keejjee maqqoo & 30 \\
\hline
\end{tabular}

Table 2. Uddoo and base sixty numerations

\begin{tabular}{cccccc}
\hline Number & Name in Kafinoono & In base sixty & Number & Name in Kafinoono & In base sixty \\
\hline 60 & Ikkee uddoo & 10 & 102 & Ikkee uddaa aabba guttoo & 1(42) \\
\hline 61 & Ikkee uddaa ikkoo & 11 & 103 & Ikkee uddaa aabbaa keemo & $1(43)$ \\
\hline 62 & Ikkee uddaa guttoo & 12 & 104 & Ikkee uddaa aabba awuddoo & $1(44)$ \\
\hline 63 & Ikkee uddaa keemo & 13 & 105 & Ikkee uddaa aabbaa uuchoo & 1(45) \\
\hline 64 & Ikkee uddaa awuddoo & 14 & 106 & Ikkee uddaa aabbaa shirittoo & $1(46)$ \\
\hline 65 & Ikkee uddaa uuchoo & 15 & 107 & Ikkee uddaa aabbaa shabaattoo & $1(47)$ \\
\hline 66 & Ikkee uddaa shiittoo & 16 & 108 & Ikkee uddaa aabbaa shimittoo & 1(48) \\
\hline
\end{tabular}

Table 3. Fractional terms in Kafa Culture

\begin{tabular}{ccc}
\hline Fractional term & Description in English & Mathematical symbol \\
\hline Qato & Half of an object & $1 / 2$ \\
\hline Heecoo & Quarter of an object & $1 / 4$ \\
\hline Woocoo & One eighth of an object & $1 / 8$ \\
\hline Wollicoo & One sixteenth of an object & $1 / 16$ \\
\hline Qachaa heecoo & Half and quarter $(1 / 2+1 / 4=3 / 4)$ & $3 / 8$ \\
\hline Heecaa Woocoo & Quarter and one eighth $(1 / 4+1 / 8=3 / 8)$ & $3 / 16$ \\
\hline Woocaa Wollicoo & One eighth and one sixteenth $(1 / 8+1 / 16=3 / 16)$ \\
\hline Wocaacilloo & One thirty second $(1 / 32)$ \\
\hline Wollicaa wocaacilloo & One sixteenth and one thirty second $(1 / 16+1 / 32=3 / 32)$ \\
\hline
\end{tabular}

Table 4. Description of indigenous units of length measurements and their approximation

\begin{tabular}{ccc}
\hline Local unit of length & Description & Estimation in Western unit \\
\hline yafero & The thickness of one middle finger & 1 finger $\cong 2.5 \mathrm{~cm}$ \\
\hline Ciixo & Distance from the tip of thumb to the tip of middle finger & 1 finger span $\cong 25 \mathrm{~cm}$ \\
\hline Hiroo & Distance from elbow to the tip of middle finger & $1 \mathrm{hand} \cong 50 \mathrm{~cm}$ \\
\hline Shaadoo & One step or stride & $1 \mathrm{stride} \cong 1 \mathrm{~m}$ \\
\hline \multirow{2}{*}{ Matoo } & Hug - distance from the tip of middle finger in the left hand to the tip of middle finger in the right & $1 \mathrm{hug} \cong 2 \mathrm{~m}$ \\
hand when stretched.
\end{tabular}

ikkoo (one), guttoo (two), keemo (three), awuddoo (four) and uuchoo (five), maqqoo (six), ikkee maqqaa ikkoo (seven); ikkee maqqaa gutto (eight), ikkee maqqaa keemo (nine), ikkee maqqaa awuddoo (ten), ikkee maqqaa uuchoo (11), guttee maqqoo (12). We have presented the relationship between maqqoo counting to base six numeration systems as in Table 1.

In Kafa culture, there is inter-connection between maqqoo and uddoo counting systems. Aashiree maqoo (ten groups of six) represents ikkee uddoo (one sixty).

As indicated in the table, people in Kafa use number in mathematical words. These number words and descriptions assist every individual to easily understand the numeral in base six. For example, 17 in maqqoo counting can described as two maqqoo and five. It shows that 25 in base six (maqqoo) numeration. Similarly, uddoo counting is used in the cultural setting. Examples of uddoo numeration are given in Table 2.

These mathematical systems are well connected with base six and base sixty numeration systems. For example, the name guttee uddaa aaraa shirittoo describes the number 2(16) in base sixty which is the same as 136 in base ten.

\section{Fraction and Fractional Terms}

Fractions represent part of a whole. As Baratto, Bergman, and Hutchison (2009), indicates the history of fraction was related to the Latin word fractio which is attached to breaking objects into pieces. Thus, it refers to a whole divided into its parts. In Kafa cultural setting, these mathematical ideas and practices are exercised interwoven both in the language of communication and in the cultural experiences. Table 3 presents descriptions of fractions in Kafa people.

As presented in Table 3, the study confirmed the existence of specific mathematical ideas like fractional terms described in the language and convention of people of Kafa in the socio cultural setting. Conversion and Unit of Measurement

The result of this study showed that people practice specific cultural units of measurements that have specific relationships among each other. The following table presents each indigenous unit of measurement as summary of the results of the study.

As Table 4 presents, yafero, ciixo, hiroo, shaaadoo and matoo are common units of length measurements in Kafa people's agricultural setting. 
Table 5. Description of indigenous area units and their relationships with standard units

\begin{tabular}{|c|c|c|}
\hline Area units & Relationship between the units & The estimate measure of area in Western units \\
\hline Haaroo & & One haaroo $=50 \mathrm{M}^{2}$ \\
\hline Ikkee Angoo (ox plow) & One angoo $=20$ haaroo & One ox plow $=1000 \mathrm{M}^{2}$ \\
\hline Shanee goyo (One week's farm) & One week's farm $=5$ ox plow & 5000 Square Meter \\
\hline Ikke hektaaro (One Hectare) & One Hectare $=$ two weeks farm $=10$ ox plow & One Hectare $=10,000 \mathrm{M}^{2}$ \\
\hline Ikkee gaachoo (one gaachoo) & One gaachoo $=40$ hectare $=400$ ox plow & One gaachoo $=400,000 \mathrm{M}^{2}$ \\
\hline
\end{tabular}

Table 6. Summary of indigenous units of weight

\begin{tabular}{|c|c|c|c|}
\hline Local unit of weight & Description & Estimation in Western unit & Remark \\
\hline Kubaayo & A device that people measure the amount of cereals and agricultural products & One kubaayo $=1 \mathrm{Kg}$ & \\
\hline Qunno & A device that contains six kubaya of cereal & One Qunno $=6 \mathrm{Kg}$ & \\
\hline Daawulloo & A bag that contains 20 qunna of cereal & One Daawulloo $=120 \mathrm{Kg}$ & \\
\hline Farasulloo & The amount of honey or coffee equivalent to $17 \mathrm{Kg}$ & One Farasulloo $=17 \mathrm{Kg}$ & \\
\hline
\end{tabular}

Table 7. Summary of content analysis on the integration of indigenous number and number sense (INNS) in primary school curriculum

\begin{tabular}{|c|c|c|c|c|c|c|}
\hline \multirow{2}{*}{$\begin{array}{c}\text { Sub content themes on number and } \\
\text { Number Sense (NNS) }\end{array}$} & \multirow{2}{*}{ No of Content } & \multicolumn{4}{|c|}{ Grade level } & \multirow[b]{2}{*}{ Total } \\
\hline & & G1 & G2 & G3 & G4 & \\
\hline \multirow{3}{*}{ Counting, ordering, pattern and operation } & Total content & 17 & 22 & 8 & 8 & 56 \\
\hline & IC & 0 & 0 & 0 & 0 & 0 \\
\hline & $\%$ of IC & 0 & 0 & 0 & 0 & 0 \\
\hline \multirow[b]{2}{*}{ Fraction and Operation on Fractions } & Total content & 2 & 5 & 6 & 7 & 20 \\
\hline & IF & 2 & 2 & 2 & 4 & 10 \\
\hline \multirow{3}{*}{ Measuring and units of measurement } & Total content & 3 & 14 & 10 & 24 & 51 \\
\hline & IM & 3 & 3 & 3 & 6 & 15 \\
\hline & $\%$ of IM & 100 & 21 & 30 & 25 & 29.41 \\
\hline \multirow{3}{*}{ Total } & Total & 22 & 41 & 24 & 40 & 127 \\
\hline & INNS & 5 & 5 & 5 & 10 & 25 \\
\hline & $\%$ of INNS & 22.7 & 12.2 & 20.8 & 25 & 19.69 \\
\hline
\end{tabular}

Area and relationships among area units is another mathematical practice observed in the agricultural setting of Kafa with regard to conversion and comparison. Table 5 presents indigenous units of area in Kafa people.

As Table 5 presents, people of Kafa use different indigenous units for area measurement in agricultural setting. In this regard, the study investigated that haaroo (section of ox-plow land), angoo (ox-plow), shane goyoo (week's farming), hektaaroo (hectare) and gaachoo as indigenous units for measuring agricultural field. Another important finding of this study was people's cultural units of weight measurement. Table 6 presents the summary of the results of weight measurement units in the area.

As the summary table presents, people of Kafa use kubaayo, qunno, daawulloo and farasulloo for measuring weight of objects. The finding of the study further showed that the local units of weight measurement in Kafa are dependent on the type of agricultural product. For example, the weight of one kunna of coffee (ikke qunnee bunoo) with hull is different from the weight of one kunna of teff. While the weight of one kunna of teff is estimated as $6 \mathrm{~kg}$, that of one kunna of coffee with hull is $3.36 \mathrm{~kg}$.

Indigenous Number and Number Sense in School Curriculum

Indigenous number sense in this paper refers to counting, number pattern and algorithms related to maqqoo and uddoo counting, fraction and fractional terms and measurement and units of measurement included in primary school curriculum.

The result of content analysis as depicted in Table 7 showed that indigenous counting (IC) in maqqoo and uddoo were not included in school curriculum as content. The analysis further showed that the percentage of inclusion of indigenous fraction (IF) and indigenous measurement (IM) in primary school curriculum were $50 \%$ and $29.41 \%$ respectively.

The result of overall indigenous number and number sense (INNS) contents included in primary curriculum, however, was $19.69 \%$. This shows that the level of inclusion of indigenous number and number sense in primary curriculum could be levelled as low.

More specifically, indigenous counting in six (maqqoo) and in sixty (uddoo) were the overlooked dimension in the strands of number in primary school curriculum. Our key informants involved into our study also confirmed that indigenous way of counting in maqqoo and uddoo were not included in the curriculum. For example, Mr. Gawo, a lower primary school teacher described the issue as follows "the idea of counting in indigenous ways such as maqqoo and uddoo are not included in the curriculum materials (Mr. Gawo, March 31/2019”.

Teachers involved in our study confirmed that indigenous way of counting was not integrated in school curriculum of Kafa, Ethiopia. Our key informants also confirmed the inclusion of fractional ideas found in the cultural setting in to school curriculum as content. For example, Ms. Gaboogi, one of our teacher informants had the following to say.

When I see the detail of contents in the texts that I am teaching, among numbers and number related concepts, fraction and fractional concepts are well connected with the cultural mathematical descriptions (Ms. Gaboogi; March 26/2019). 
Table 8. Percentage of Indigenous Units of Measurement in school curriculum

\begin{tabular}{|c|c|c|c|c|c|c|c|c|c|c|c|c|c|c|c|c|}
\hline \multirow[b]{2}{*}{ No } & \multirow{2}{*}{$\begin{array}{l}\text { Category } \\
\text { Codes }\end{array}$} & \multicolumn{3}{|c|}{ Grade One } & \multicolumn{3}{|c|}{ Grade Two } & \multicolumn{3}{|c|}{ Grade Three } & \multicolumn{3}{|c|}{ Grade Four } & \multicolumn{3}{|c|}{ Total } \\
\hline & & $\begin{array}{c}\text { Total } \\
\text { No }\end{array}$ & $\begin{array}{c}\text { IU } \\
\text { Content } \\
\end{array}$ & $\%$ & $\begin{array}{c}\text { Total } \\
\text { No }\end{array}$ & $\begin{array}{c}\text { IU } \\
\text { Content }\end{array}$ & $\%$ & $\begin{array}{c}\text { Total } \\
\text { No }\end{array}$ & $\begin{array}{c}\text { IU } \\
\text { Content }\end{array}$ & $\%$ & $\begin{array}{c}\text { Total } \\
\text { No }\end{array}$ & $\begin{array}{c}\text { IU } \\
\text { Content }\end{array}$ & $\%$ & $\begin{array}{c}\text { Total } \\
\text { No }\end{array}$ & $\begin{array}{c}\text { IU } \\
\text { Content }\end{array}$ & $\%$ \\
\hline 1 & IUL & 1 & 1 & 100 & 4 & 0 & 0 & 2 & 0 & 0 & 6 & 0 & 0 & 13 & 1 & 7.69 \\
\hline 2 & IUC & 1 & 1 & 100 & 2 & 0 & 0 & 2 & 0 & 0 & 4 & 0 & 0 & 9 & 1 & 11.11 \\
\hline 3 & IUW & 1 & 1 & 100 & 1 & 0 & 0 & 2 & 0 & 0 & 3 & 0 & 0 & 7 & 1 & 14.29 \\
\hline 4 & IUA & & & & & & & & & & & & & & & \\
\hline 4 & IUM & & & & 2 & 2 & 100 & 2 & 2 & 100 & 4 & 4 & 100 & 8 & 8 & 100 \\
\hline 5 & IUT & & & & 5 & 1 & 20 & 2 & 1 & 50 & 7 & 2 & 29 & 14 & 4 & 29 \\
\hline & Total & 3 & 3 & 100 & 14 & 3 & 21 & 10 & 3 & 30 & 24 & 6 & 25 & 51 & 15 & 29.41 \\
\hline
\end{tabular}

The extract of the teacher's interview confirmed that contents on number and number sense contained the indigenous fractional terms of Kafa people in its curriculum. In this case, the data shows the curriculum material contains indigenous fractional terms as content under the strand as part of number. However, the analysis of the contents arrangement indicated that $1 / 3$ was included as content prior to $1 / 4$ which is against the principle of socio cultural theory of learning which promotes the curriculum content organization based on children's prior experience. Culturally sensitive pedagogy advices curriculum workers to present contents inter connected with people's culture prior to the new content to the culture of people (Shizha, 2014). Furthermore, some of fractions and fractional descriptions such as qachaa-heecoo and heecaa-woocoo were nonexistent in the primary school curriculum material. Teachers involved in our study argued that the problem occurred it was because contextualization was done only on the language of the curriculum. For example, regarding the issue $\mathrm{Mr}$. Gawo said the following.

The difference between the content of lower primary school mathematics in Kafa and the nationally prepared curriculum materials is only on the language of the content (Mr. Gawo, March 31/2019).

Teachers involved in our study confirmed that mere focus only on the translation of the nationally prepared curriculum affected meaningful contextualization, in this regard.

As indicated in Table 7, 29.41\% of the whole measurement related contents of school curriculum was related to indigenous units as content. However, further observation on the detail of the content analysis table shows that indigenous measurement related contents included in the curriculum material were skewed to money and time units.

The result depicted in Table 8 indicates that the percentages of indigenous units of money and time were $100 \%$ and $29 \%$ in primary curriculum. On the other hand, the percentage of inclusion of indigenous unit of length (IUL), capacity (IUC), weight (IUW) and area (IUA) were $7.69 \%, 11.11 \%$ and $14.29 \%$ respectively. This shows that the level of inclusion of indigenous units in primary curriculum was skewed to money and time units than others. Despite this, our informants had confirmed that indigenous units were integrated in school curriculum in gross. Ms. Gaboogi described

When people in Kafa measure the length of rope, they measure using their hands. When they measure the distance between two poles inside their farm field, they measure using their strides. These types of length measurement units are included in grade one students' curriculum material (Ms. Gaboogi; March 26/2019).

As indicated in the above extract, Ms. Gaboogi indicated that indigenous units of length are among indigenous contents included in the lower primary school as content. Mr. Gawo, a teacher in one of lower primary schools of Kafa, described the inclusion of indigenous units of length and capacity in the lower primary school curriculum when he pointed out the issue of inclusion as indicated below.

In house construction; xaamo (foot), hiroo (hand), ciixo (finger span) and yaferoo (finger) are common. In measuring capacity the objects they use doolloo (cup), qondoo (pitchers), goto (granary) and the like. These units of measurements are part of school curriculum (Mr. Gawo., March 25/2019).

As the extract indicates indigenous units of length measurements were included in the lower primary school curriculum as content. Having identified the indigenous number and number sense integrated in lower primary school curriculum, we have explored the details of the activities and exercises included in the curriculum if the indigenous number and number sense were consistently integrated in the details of the exercises.

The result of content analysis in Table 9 indicates that $21.29 \%$ of the whole contents of examples, exercises and activities were related to indigenous fraction. Furthermore, $4.61 \%$ of the activities and exercises on measurement contained indigenous units and practices related to indigenous measurements.

However, the overall percentage of inclusion of indigenous number and number sense in exercises and activities was $5.87 \%$ which shows that the level of inclusion was very low.

\section{DISCUSSION}

The intent of this study was to explore indigenous number and number sense integrated in the school curriculum and to find out its level of inclusion in the curriculum. The key issues pertaining to the finding of this study are offered in the following sub sections.

Indigenous Number and Number Sense in Agricultural Setting of Kafa, Ethiopia

According to Fisher (1993), number and number sense refers to mathematical systems related to concepts, rules and algorithms that emanate as a result of counting and number pattern. In this regard, this study found that base six and base sixty numeration systems, fractions and measurement related concepts are found connected with people's cultural practices. 
Table 9. Percentage of indigenous number and number sense in the exercises and activities of school curriculum

\begin{tabular}{|c|c|c|c|c|c|c|}
\hline \multirow{2}{*}{$\begin{array}{c}\text { Sub content themes on number and Number } \\
\text { Sense (NNS) }\end{array}$} & \multirow{2}{*}{$\begin{array}{c}\text { No of exercises and } \\
\text { activities }\end{array}$} & \multicolumn{4}{|c|}{ Grade level } & \multirow[b]{2}{*}{ Total } \\
\hline & & G1 & G2 & G3 & G4 & \\
\hline \multirow{3}{*}{ Fraction and Operation on Fractions } & Total exercise & 15 & 72 & 88 & 182 & 357 \\
\hline & IFR & 11 & 15 & 44 & 6 & 76 \\
\hline & $\%$ of IFR & 73.3 & 20.8 & 50 & 3.3 & 21.29 \\
\hline \multirow[b]{2}{*}{ Measuring and units of measurement } & Total exercise & 65 & 1710 & 2350 & 216 & 4341 \\
\hline & IMR & 45 & 45 & 94 & 16 & 200 \\
\hline \multirow{3}{*}{ Total } & Total & 80 & 1782 & 2438 & 398 & 4698 \\
\hline & INNSE & 56 & 60 & 138 & 22 & 276 \\
\hline & $\%$ of INNSE & 70 & 3.37 & 5.66 & 5.53 & 5.87 \\
\hline
\end{tabular}

Counting in maqqoo and uddoo as Base Six and Base Sixty Numeration System

According to Landon (1993), numeration system is a set of rules for establishing the names of numbers. In Kafa culture, the conventional names in maqqoo and uddoo counting systems have systematic rules which are built on base six and base sixty numeration systems. This finding can be seen as an extension of the work of Bishop (1997) who indicated that counting as a socio-cultural activity includes "mental abilities of numerical methods".

\section{Fractions and Fractional Descriptions as Cultural Practices}

Fractions represent part of a whole. As Baratto et al (2009), indicates the history of fraction is related to the Latin word fractio which is attached to breaking objects into pieces. The study found that such experiences are evident in Kafa as embedded in their activities. In Kafa culture, fractional ideas are used in connection with day-to-day activities and cultural convection such as machago of shared cattle keeping in Kafa, Ethiopia. Accordingly, the study confirmed what was reported in the former studies that specific mathematical ideas are found interwoven in the language, convention and agreement of people in the socio-cultural setting (Bishop, 1988; Ernest, 1991, Sriraman \& English, 2010).

\section{Conversion and Unit of Measurement}

The finding of this study showed that people in Kafa use their body parts and physical objects for measuring objects. The study found that yafero, ciixo, hiroo, shaaadoo and matoo as indigenous units of length in Kafa. Furthermore, it was found that haaro, ox plow (angoo), week farming (shanee goyo), hectare (hektaaro) and gaachoo are indigenous units of area and kubaayo, qunno, daawulloo and farasulloo as indigenous unit of weight in agricultural setting of people in Kafa, Ethiopia. There are also studies conducted in other setting that reported people's use of local and contextual tools and units of measurement. For example, a study conducted by Amit, and Qouder (2017) indicated that body parts of people in Bedoli is common unit of measurement for length. Similarly, a study by Hilluf (2015) from a study conducted in Khimra people of Ethiopia reported similar finding. Though this study investigated additional units such as haaroo, shanee goyo (week farm) and gaachoo as area units, the study agrees with Hilluf (2015)'s finding in that people of Khmra people in Ethiopia use pair of oxen to measure land area which is comparable with angoo of the Kafa people. Regarding indigenous units of weight our study's finding disagrees with Amit, and Qouder (2017)'s study conducted in Bedouins in Israel reported that people use reten $(3 \mathrm{~kg})$, wakeh $(2509 \mathrm{~kg})$, and gentar without considering the type of crop for weight measurement.
Indigenous Number and Number Sense of Kafa People in School Curriculum

Empirical studies conducted in Africa regarding Ethnomathematics (Arcavi, 2003; Mogari, 2014; Mosmege, 2017; Orey \& Rosa, 2011) recommended that mathematics curriculum should encompass the cultural mathematical knowledge without selective validation so as to assure students' meaningful learning. For example, Orey and Rosa (2011, p. 42) argued that school mathematics should value, reinforce and include the knowledge of students instead of disregarding. With respect to this, our study found that among number and number related knowledge of people in Kafa, indigenous fraction and fractional terms were highly emphasized and integrated in the lower primary school curriculum in Kafa, Ethiopia. On the other hand, the study identified that indigenous units of measurements of time and money were the overtly recognized and included indigenous units of measurements in school curriculum than others. Such representation reflects partial validation of indigenous mathematical knowledge in the curriculum (Phiri, 2008, p. 68). Partial validation, in this case, refers to the inclusion of some of the indigenous contents leaving some equally important contextual contents in the curriculum.

The finding of this study extended the result of study conducted in Africa. Phiri (2008) who based on a study conducted on representation of Indigenous science to school science concluded that in African school curriculum, Indigenous Knowledge is partially validated. In addition, Magni (2017, p. 443) pointed out that school mathematics should keep equilibrium in validating both local and non local knowledge systems. Our study found that there exist variations among contents of primary school curriculum pertaining to its level of inclusion of indigenous number and number sense. It was found that indigenous counting was less recognized and ignored dimensions among indigenous number and number sense included in school curriculum in Kafa, Ethiopia.

The result of the study indicated that there existed the problem of consistency in laying foundation to use indigenous number and number sense in the lower primary school curriculum. The result of content analysis showed that some Indigenous number and number sense and indigenous units were largely acknowledge and included in the curriculum as content but excluded from the exercises, activities and examples of the school curriculum.

The study thus found that there existed variations in curriculum workers' attempt to integrate indigenous number and number sense of Kafa people in school curriculum. For example, while indigenous unit of money and time cover higher coverage from the content section to exercises, indigenous unit of length and capacity were limited to content alone. In this regard, contextualization of contents of the 
curriculum which was echoed in the syllabus did not work for every strand and to all indigenous number related content properly.

Despite contextualization entails the use of content, examples and applications of scientific principles to situations that are familiar to students; lived experience and world views (Gwekwere, 2016); contextualization has been exercised in lower primary school curriculum of Kafa, Ethiopia in its limited sense. In the primary school curriculum preparation process, contextualization of primary school mathematics relied on the use of local language, local pictures and local names as major tools. In addition, the level of recognition given to indigenous knowledge varies from specific content to content. For example, while all non indigenous units of measurements were used in the activities and word problems, most indigenous units of measurement were excluded from word problems and practice exercises. Thus, in the continuum of indigenization of school curriculum, the attempt to integrate indigenous number and number sense is inconsistent and can be labelled as low level which calls for curriculum improvement.

\section{CONCLUSION AND IMPLICATION}

Indigenous number and number sense, as a system of mathematics in a particular setting, deals with pattern, order, structure and relationships among number and counting related mathematical concepts (Fisher, 1993; FitzSimons, 2002, p. 17). In this regard, our study found that base six and sixty numeration system, fraction and fractional descriptions and relationship among local units of measurement as number and number sense in agricultural setting of people in Kafa. The implication of the finding is that mathematical concepts are found interwoven the cultural practice of people. Therefore, mathematics education in Ethiopia needs to be geared towards mathematizing.

According to Ronah (2017), curriculum should reflect society's values and knowledge systems and its development should regard the indigenous knowledge and day-to-day experiences as point of opening. In this regard, our study found that indigenous number and number sense is selectively validated in the primary school curriculum of Kafa, Ethiopa. More specifically, the study showed that of the different indigenous contents, only indigenous fraction and some indigenous unit of measurements were included in the school curriculum. This shows that indigenous number and number sense of people in Kafa was partially validated and included in school curriculum. At this juncture, it is concluded that the inclusion of some of indigenous number related contents was not well planned and organized but it was random in Kafa. They were integrated as sudden match of contents occurred in the process of curriculum preparation. The implication of this finding is that school curriculum of Kafa, Ethiopia need to be revised in a way it contains Indigenous number and number sense.

Author contributions: All authors were involved in concept, design, collection of data, interpretation, writing, and critically revising the article. All authors approve final version of the article.

Funding: The authors received no financial support for the research and/or authorship of this article.

Declaration of interest: Authors declare no competing interest.

Data availability: Data generated or analysed during this study are available from the authors on request.

\section{REFERENCES}

Adam, S., Alangui, W., \& Barton, B. (2003). A comment on: Rowlands \& Carson "Where would formal, academic mathematics stand in a curriculum informed by ethnomathematics? A critical review". Educational Studies in Mathematics, 52, 327-335. https://doi.org/10.1023/A:1024308220169

Alberta Education (2007). Primary programs framework-curriculum integration: Making connections. Alberta.

Amit, M., \& Qouder, F. A. (2017). Weaving culture and mathematics in the classroom: The case of bedouin ethnomathematics. In Ethnomathematics and its Diverse Approaches for Mathematics Education (pp. 23-50). Springer, Cham. https://doi.org/10.1007/978-3-31959220-6_2

Arcavi A. (2003). Everyday and academic mathematics in the classroom. Journal for Research in Mathematics Education, 11, 12-29. https://doi.org/10.2307/749962

Areaya, S. (2008). Policy formulation curriculum development and implantation in Ethiopia: The book center, Addis Ababa.

Ascher, M., \& Ascher, R. (1997). Ethnomathematics. In A. B. Powell, \& M. Frankenstein (Eds.), Ethnomathematics: Challenging eurocentrism in mathematics education (pp. 25-50). State University of New York Press, Albany.

Ayalew, Y., \& Areaya, S. (2021). Sociocultural mathematics in Ethiopia: A glocal view of Dire Dawa context. Journal of Mathematics and Culture, 15(3), 66-85.

Baratto, S., Bergman, B., \& Hutchison, D. (2009). Hutchison's basic mathematical skill with geometry (8th ed.). McGraw-Hill Campanies.

Bishop, A. J. (1988). Mathematics education in its cultural context. Educational Studies in Mathematics, 19(2), 179-191. https://doi.org/10.1007/BF00751231

Creswell, J. W. (2007). Qualitative inquiry and research design: Choosing among five approaches (2nd ed.). Sage Publications, Inc.

D'Ambrosio, U. (1985). Association ethnomathematics and its place in the history and pedagogy of mathematics. For the Learning of Mathematics, 5(1), 44-48.

D'Ambrosio, U. (1990). The role of mathematics education in building a democratic and just society. For the Learning of Mathematics, 10 (3), 20-23.

Davison, D. M., Miller, K. W., \& Metheny, D. L. (1995). What does integration of science and mathematics really mean?. School Science and Mathematics, 95(5), 226-230. https://doi.org/10.1111/j.19498594.1995.tb15771.x

Eleni, T. (1992). Indigenous African education as a means for understanding the fullness of life: Amara traditional education. Journal of Black Studies, 23(1), 7-26. https://doi.org/10.1177/002193479202300102

Ernest, P. (1991). The philosophy of mathematics education. Routledge Falmer.

Faris, S. B. (2012). Restoring local spiritual and cultural values in science education: The case of Ethiopia (Doctoral dissertation), University of Toronto. https://tspace.library.utoronto.ca/bitstream/1807/33991 /1/Faris_Solomon_B_201211_PhD_thesis.pdf 
Fatima, R. (2014). Role of mathematics in the development of society. National Meet on Celebration of National Year of Mathematics, 20(2), 20-22.

Finkelstein, L. (2014). Fundamental concepts of measurement. ACTA IMEKO, 3(1), 10-15. https://doi.org/10.21014/acta_imeko.v3i1.191

Fischer, R. (1993). Mathematics as a means and as a system. In S. Restivo, J. P. van Bendegem, \& R. Fischer (Eds.), Math worlds: Philosophical and social studies of mathematics and mathematics education (pp. 113-133). State University of New York Press.

Fitzsimons, G. E. (2002). What Counts as Mathematics? Technologies of Power in Adult and Vocational Education. Kluwer Academic Publishers. https://doi.org/10.1007/0-306-47683-5

Gwekwerere, Y. (2016). Schooling and the African Child. In African indigenous knowledge and the sciences (pp. 33-46). SensePublishers, Rotterdam. https://doi.org/10.1007/978-94-6300-515-9_3

Hailu N. W. (2016). Ethnomathematics in Ethiopia: Futile or fertile for mathematics education? Momona Ethiopian Journal of Science, 8(2), 146-167. https://doi.org/10.4314/mejs.v8i2.4

Hsieh, H.-F., \& Shannon, S. E. (2005). Three approaches to qualitative content analysis. Qualitative Health Research, 15(9), 1277-1288. https://doi.org/10.1177/1049732305276687

Kaino, L. (2013). Traditional knowledge in curricula designs: Embracing indigenous mathematics in classroom instruction. Studies of Tribes and Tribals, 11(1), 83-88. https://doi.org/10.1080/0972639X.2013.11886669

Kelly, A. V. (2004). The curriculum: Theory and practice. Sage Publications.

Landon, C. R. (1993). American Indian mathematics traditions and contributions. Portland Public Schools Geocultural Baseline Essay Series.

Loepp, F. L. (1999). Models of curriculum integration. The Journal of Technology Studies, 25(2), 21-25. https://doi.org/10.21061/ jots.v25i2.a.6

Magni, G. (2017). Indigenous knowledge and implications for the sustainable development agenda. European Journal of Education, 52(4), 437-447. https://doi.org/10.1111/ejed.12238

Menon, U. (2013). Mathematisation-vertical and horizontal. In Fifth International Conference to Review Research on Science, Technology and Mathematics Education (epiSTEME 5) (pp. 260-267).

MOE (2002). The education and training policy and its implementation. Addis Ababa: Ministry of Education.

MOE (2014). Active learning in mathematics and science learning (Grade 7 and 8). Addis Ababa: Ministry of Education.

MoE, ESC (2018). Ethiopian education development road map (2018 - 2030). An integrated executive summary. Addis Ababa: Ministry of Education.

Mogari, L. D. (2014). A global perspective of mathematics teaching: implications for South Africa. http://hdl.handle.net/10500/19003

Mosimege, M. (2017). Mathematical concepts from community elders: exploring the connection between ethnomathematical contexts and classroom practices. ETD-Educação Temática Digital, 19(3), 667-686. https://doi.org/10.20396/etd.v19i3.8648368
Munro, S. L. (2017). Curriculum Integration: Magnifying the teacher experience with curriculum integration (Master's thesis), University of Sydney.

Nair, S. B., \& Tefera A. (2017). Indigenous knowledge in Ethiopian school curriculum. Review of Social Sciences, 18(2), 89-95.

Nsamenang, A. B., \& Tchombe, T. M. S (2011). Hand book of educational theories and practices: A generative teacher education curriculum. Human Development Resource Centre (HDRC), Bamenda, North West Region (Cameroon). http//: www.thehdrc.org

Nunes, T. (1992). Ethnomathematics and everyday cognition. In D. Grouws (Ed.), Handbook of research on mathematics teaching and learning (pp. 557-574). New York, Macmillan.

Oliva, F. P. (2005). Developing the curriculum (6th ed.). Pearson Education Inc.

Olivastro, D. (1993). Ancient puzzles: Classic brainteasers and other timeless mathematical games of the last ten centuries. Bantan Books.

Orey, D. C., \& Rosa, M. (2006). Ethnomathematics: Cultural assertions and challenges towards pedagogical action. Journal of Mathematics and Culture, 1(1), 57-78.

Orey, D. C., \& Rosa, M. (2011). Ethnomathematics: The cultural aspects of mathematics. Revista Latinoamericana de Etnomatemática, 4(2), 3254.

Orey, D. C., \& Rosa, M. (2014). The borrowers: Using transportation, addresses, and paralelepípedos to prompt creativity using ethnomodeling. In S. Careira, M. Amado, K. Jones, \& H. Jacinto (Eds.), Proceedings of the Problem@Web International Conference: Technology, creativity and affect in mathematical problem solving (pp. 168-178). Universidde do Algarve.

Orey, D., \& Rosa, M. (2004). Ethnomathematics and the teaching and learning mathematics from a multicultural perspective. In F. Favilli (Ed.), Ethnomathematics and mathematics education: Proceedings of the 10th international congress of mathematics education, Copenhagen (pp. 139-148).

Ornstein, A. C., \& Hunkins, F. P. (2018). Curriculum foundations, principles and issues (7th ed.). Pearson Education Limited.

Paulos, M. (1976). Traditional institutions and traditional elites: The role of education in the Ethiopian body-politic. African Studies Review, 19(3), 79-93. https://doi.org/10.2307/523876

Phiri, A. D. K. (2008). Exploring the integration of indigenous science in the primary school science curriculumin Malawi (Doctoral dissertation), Virginia Polytechnic and State University, Blacksburg, Virginia.

Pinar, W. F. (2004). What is curriculum theory? Louisiana state University: Lawrence Erlbaum Associations, Inc.

Reddu, H. (2015). Everyday mathematics in Ethiopia: The case of the Khimra people (PhD thesis), Department of Science and Mathematics Education, Addis Ababa University, Ethiopia.

Ronah, J. C. (2017). Indigenous knowledge in the school curriculum: teacher educator's perceptions of place and position (Master's thesis), Nelson Mandela University, Port Elizabeth, South Africa.

Rossman, G., \& Rallis, S. (2012). Learning in the field (3rd ed.). Sage Publications Inc.

Schumacher, D. H. (1995). Five levels of curriculum integration defined, refined, and described. Research in Middle Level Education, 18(3), 73-94. https://doi.org/10.1080/10825541.1995.11670055 
Seehawer, M. (2018). South African science teachers' strategies for integrating indigenous and western knowledges in their classes: Practical lessons in decolonisation. Educational Research for Social Science, 7, 91-110. https://doi.org/10.17159/2221-4070/2018/ v7i0a7

Shizha, E. (2014). Integrating knowledge system and the curriculum. In G. Emeagwali, \& G. J. S. Dei (Eds.), African indigenous knowledge and the disciplines (pp. 113-129). Sense Publishers. https://doi.org/10.1007/978-94-6209-770-4_11

Sriraman B., \& English L. (2010). Theories of mathematics education: Seeking new frontiers. Springer-Verlag. https://doi.org/10.1007/ 978-3-642-00742-2
Tesfamichael, S. A., Nakkeen, A. H., Tumbo, T., \& Grey, P. (2021). Curriculum implications of using ethnomathematics to promote student learning in Ethiopia. Journal of Mathematics and Culture, 15(3), 86-123.

TGE (1994). The education and training Policy EEP 86. Addis Ababa, Ethiopia.

Webb, P. (2013). Xhosa indigenous knowledge: Stakeholder awareness, value and choice. International Journal of Science and Mathematics Education, 11, 89-110. https://doi.org/10.1007/s10763-012-9370-z

Yin, R. (2011). Qualitative research from start to finish. The Guilford Press. 